Egypt J. Aquat. BioL\& Fish. Vol. 10,No.l 139-150(2006)ISSN 1110-6131

\title{
PRECAUTIONARY TARGET REFERENCE POINTS (TRPs) FOR CARANGID FISHERIES MANAGEMENT IN THE GULF OF SUEZ, RED SEA, EGYPT
}

\author{
Usama S. A. Khalifa, and Sahar F. Mehanna \\ National Institute of Oceanography and Fisheries, Egypt. \\ klialifausa@yahoo.com \\ Keywords: Red Sea, Gulf of Suez, Carangidae, purse-seine, trawl, Schaefer, \\ sustainability, precautionary reference points, management.
}

\begin{abstract}
Gamily Carangidae includes the most abundant species in purse-seine fishery in the Gulf of Suez, where it constitutes about $39 \%$ and $6 \%$ of the total production of purse-seine and trawl fisheries respectively. Fishery statistics (catch, effort and catch per unit of fishing effort) of the carangid fish exploited by purse-seine and trawl fisheries during the fishing seasons from 1979/80 to 2003/04 were analysed to assess the effect of the two types of fishing gears on the annual carangid production. The maximum sustainable yield (MSY) and the corresponding level of fishing effort $\left(f_{\text {Kilcv }}\right)$ were estimated as limited reference point using the

\section{IVlo Y}

Schaefer surplus production model. In addition, $2 / 3 \mathrm{f}_{\mathrm{MSY}}$ and the yield corresponding to this effort were calculated as precautionary target reference points. The obtained results indicated that carangids were overexploited in the Gulf of Suez. For achieving the precautionary target reference points, it was recommended to reduce the fishing by about $59.6 \%$ and $47.2 \%$ for trawl and purse-seine fisheries respectively. In general, the standardized fishing effort of both gears should be reduced by $46.9 \%$. The results showed that reduction of fishing effort to such levels will increase the marginal revenue in term of CPUE by about 33\%. Regulating mesh size and defining closed area are recommended as well as studying the gear selectivity and developing a geographical information system for fishing ground in the Gulf of Suez.
\end{abstract}

